\title{
Dynamics of Soybean Rust Epidemics in Sequential Plantings of Soybean Cultivars in Nigeria
}

M. Twizeyimana, Department of Crop Sciences, University of Illinois at Urbana-Champaign 61801 and International Institute of Tropical Agriculture (IITA), PMB 5320, Ibadan, Nigeria; P. S. Ojiambo, Department of Plant Pathology, North Carolina State University, Raleigh 27695 and IITA, Nigeria; G. L. Hartman, United States Department of Agriculture-Agricultural Research Service, Urbana, IL 61801 and Department of Crop Sciences, University of Illinois; and R. Bandyopadhyay, IITA, Nigeria

\begin{abstract}
Twizeyimana, M., Ojiambo, P. S., Hartman, G. L., and Bandyopadhyay, R. 2011. Dynamics of soybean rust epidemics in sequential plantings of soybean cultivars in Nigeria. Plant Dis. 95:43-50.

Soybean rust, caused by Phakopsora pachyrhizi, is an important foliar disease of soybean. Disease severity is dependent on several environmental factors, although the precise nature of most of these factors under field conditions is not known. To help understand the environmental factors that affect disease development, soybean rust epidemics were studied in Nigeria by sequentially planting an earlymaturing, highly susceptible cultivar, TGx $1485-1 \mathrm{D}$, and a latematuring, moderately susceptible cultivar, TGx 1448-2E, at 30- to 45day intervals from August 2004 to September 2006. Within each planting date, disease onset occurred earlier on TGx 1485-1D than on TGx 1448-2E, and rust onset was at least 20 days earlier on soybean planted between August and October than on soybean planted between November and April. The logistic model provided a better description of the temporal increase in rust severity than the Gompertz model. Based on the logistic model, the highest absolute rates of disease increase

were observed on soybean planted in September 2006 and October 2004 for TGx 1485-1D and TGx 1448-2E, respectively. Disease severity as measured by the relative area under disease progress curve (RAUDPC) was significantly $(P<0.05)$ negatively correlated with evaporation $(r=-0.73)$, solar radiation $(r=-0.59)$, and temperature $(r=$ $-0.64)$ but positively correlated with urediniospore concentration $(r=$ $0.58)$. Planting date and soybean cultivar significantly $(P<0.05)$ affected disease severity, with severity being higher on soybean crops planted during the wet season than those planted in the dry season. Within the wet season, planting in May and July resulted in a significantly $(P<0.05)$ lower RAUDPC than planting between August and October. Yields were significantly $(P<0.001)$ related to RAUDPC during the wet season, whereby an increase in RAUDPC resulted in a linear decrease in yield. This study suggests that selection of planting date could be a useful cultural practice for reducing soybean rust.
\end{abstract}

Soybean rust, caused by the basidiomycete Phakopsora pachyrhizi Syd. \& P. Syd., is one of the most economically important diseases affecting soybean worldwide (12). Soybean rust was first reported to affect soybean plants in Japan in 1902 (14). The spread of disease on the African continent started after the first confirmed report in Uganda in late 1996 (21), and was subsequently reported east, south, and west of Uganda between 1998 and 2001 (18,21). The largest soybean-producing country on the African continent is Nigeria (9), where the disease was first reported in 1999 (2). Since the first report of the disease, soybean rust is now endemic in all major soybean-growing areas in Nigeria (38). When no disease control measures are in place, infected plants defoliate prematurely, resulting in yield reductions. In Africa, yield losses due to soybean rust range between 20 and $80 \%$ (21).

Control of soybean rust is currently based primarily on applications of fungicides $(21,25,26)$ and planting resistant cultivars $(8,33)$. However, fungicide application adds significantly to production costs and this makes it a less viable option, especially in subsistence soybean production systems in most developing countries. Thus, the use of resistant cultivars still remains the most economical and sustainable way to manage soybean rust in Africa. In Nigeria, breeding lines and accessions that are useful sources of rust resistance genes have been identified (37) and incorporated into high-yielding and adapted cultivars (33) and this has led to the release of the rust-resistant cv. TGx 1835-10E in 2009 (8). How-

Corresponding author: P. S. Ojiambo, E-mail: peter_ojiambo@ncsu.edu

Accepted for publication 7 September 2010.

doi:10.1094/PDIS-06-10-0436

This article is in the public domain and not copyrightable. It may be freely reprinted with customary crediting of the source. The American Phytopathological Society, 2011. ever, even when sources of resistance are identified, it may take at least 5 years from the time of discovery to the availability of the resistant cultivar for use by growers. In addition, the ineffectiveness over the years of single dominant genes controlling rust resistance in soybean (12) means a continuous quest for resistance sources to develop new resistant cultivars. Similar to many other crop diseases, a successful management strategy for soybean rust will require an understanding of the epidemiology of the disease and implementation of good cultural practices in addition to the use of fungicides and resistant cultivars. Knowledge of disease epidemiology provides critical background information on factors that drive disease epidemics during the season (7). However, knowledge of the epidemiology of soybean rust and the use of cultural practices to reduce disease severity is lacking for many West African countries, including Nigeria.

Choice of planting date within the season is a cultural practice that can affect plant disease development. For example, severity of stem rust on ryegrass for the second-year seed crop was intermediate between early- and late-planted first-year plots (30), and the degree of reduction in disease severity due to planting date was greatest for the cultivars that had the highest disease severity in early-planted stands. In another study, the incidence of Fusarium wilt on lettuce sown in September was observed to be significantly higher than disease incidence in cultivars sown in either October or December (24). In an analysis of soybean rust epidemics in Taiwan, Yang et al. (40) observed that onset of soybean rust was earlier on autumn- or spring-seeded than on summer-seeded crops and disease caused less damage in the latter cropping season. In southwestern Nigeria, soybean crops are normally planted as a sole, relay, or intercrop from May until October during the wet season (1) but there are no studies that document the extent to which staggering the time of planting influences severity of soybean rust. Furthermore, information on seasonal dynamics of soybean rust in Nigeria is still lacking. Knowledge of the epidemiology of the disease will facilitate identification of important variables that 
drive disease epidemics and provide a rational basis to improve disease management by altering planting dates. Thus, the objectives of this study were to (i) characterize the temporal dynamics of soybean rust epidemics in Nigeria, (ii) determine the influence of planting date on the development of soybean rust, and (iii) identify the main physical variables that influence soybean rust epidemics in Nigeria.

\section{Materials and Methods}

Field site and test material. The study was conducted at the International Institute of Tropical Agriculture (IITA) experimental field site at Ibadan, Nigeria. The institute lies on latitude $7^{\circ} 31^{\prime} \mathrm{N}$ and longitude $3^{\circ} 45^{\prime} \mathrm{E}$ at an altitude of $210 \mathrm{~m}$ above sea level in the lowlands rainforest belt with a bimodal rainfall distribution averaging about $1,500 \mathrm{~mm}$ and temperatures of about 25 to $32^{\circ} \mathrm{C}$ during the wet season (May to October) and $900 \mathrm{~mm}$ and 19 to $35^{\circ} \mathrm{C}$ during the dry season (November to April). Two commonly grown soybean cultivars, TGx 1485-1D and TGx 1448-2E, obtained from the IITA soybean-breeding program were used in this study. TGx 1485-1D is early-maturing and highly susceptible to soybean rust, whereas TGx $1448-2 \mathrm{E}$ is late-maturing and moderately susceptible to soybean rust (34).

Planting date, experimental design, and disease and yield assessment. Treatments in this study were planting dates conducted from 31 August 2004 through 25 September 2006 at 30- to 45-day intervals for a total of 18 planting dates. A single field was divided into plots consisting of five 4-m-long rows with a spacing of 0.75 $\mathrm{m}$ between rows and $0.20 \mathrm{~m}$ between plants. Planting dates were randomly assigned to the plots and, for each planting date, cultivars were arranged in a randomized complete block design with three replications. Thus, the overall experimental design was a split-plot with planting date as the main plot and cultivar as the subplot. Plots were manually seeded, no fertilizers or pesticides were applied to all experimental plots, and disease was initiated from natural infection by $P$. pachyrhizi. During the dry season and whenever there were dry periods during the wet season, plots were irrigated twice a week for $4 \mathrm{~h}$ /day using an overhead sprinkler system. Field plots were manually weeded once during the cropping season.

Disease severity was visually assessed as percentage of leaf area affected with rust symptoms and was recorded eight times from the time of first disease symptoms through R6 growth stage (10). On each assessment date, disease severity was recorded on three individual leaflets arbitrarily selected in the bottom, middle, and upper layers of five randomly selected and tagged plants in the middle row of each plot. The mean value of disease severity across all the three canopy levels represented disease severity of the entire plant that was used in all analysis. At maturity, seed yield (grams per plant) was recorded for all the plants in the three innermost rows and the resultant yield data converted to tons per hectare for subsequent analysis.

Monitoring weather variables and urediniospore concentration. Mean, maximum, and minimum air temperature; relative humidity (RH); number of rainy days; rainfall; evaporation; and solar total radiation were monitored during the experimental period and daily observations were recorded at IITA's Geo-Spatial Station at Ibadan, which was located $500 \mathrm{~m}$ from the experimental plots. Temperature and RH were measured using a Diplex minimum and maximum thermometer (Diplex Ltd., Hertfordshire, UK) and a hygrothermograph (Model H311; Casella Measurement, Bedford, UK), respectively. Rainfall and evaporation were measured using a rain gauge (Belfort Instruments, Baltimore, MD) and a U.S. Class A pan evaporimeter (ELE International, Bedfordshire, UK), respectively, while solar radiation was measured using a pyranometer (Model R41; ELE International). The mean temperature and RH were the average of maximum and minimum temperatures and $\mathrm{RH}$ recorded daily. The daily records collected from germination to the last day of disease severity assessment (at R6 growth stage) for minimum, maximum, and mean temperature; $\mathrm{RH}$; solar radiation; and evaporation were averaged to obtain records for each planting date. Total rainfall and number of rainy days were the total natural precipitation and total number of days with natural precipitation, respectively, from germination to the last day of disease assessment.

Urediniospores during the study period between July 2004 and October 2006 were monitored by a 7-day volumetric spore trap (Burkard Scientific Ltd., Hertfordshire, UK) located in the middle of the experimental field and operated at a constant air flow rate of 10 liters $/ \mathrm{min}$. The sampling orifice was $0.5 \mathrm{~m}$ above the plant canopy. Petroleum-jelly-coated transparent tape (Melinex) mounted on a rotating drum was used in the spore sampler. Every week, the tape was replaced and the removed tape was cut into 48-mm-long segments, each representing a single day. Each segment of tape was placed on a glass slide and covered with a cover slip and scanned using a microscope at $\times 40$ to determine the number of spores deposited per day. Counts were then recorded as the number of spores per cubic meter of air sampled per day. With the help of an airborne spore and pollen atlas (11), $P$. pachyrhizi urediniospores were identified by their morphological characteristics: urediniospores are 18 to $37 \mu \mathrm{m}$ by 15 to $24 \mu \mathrm{m}$ in size, obovoid to broadly elliptical in shape with minutely and densely echinulated surfaces, and hyaline to pale yellowish brown (32).

Data analysis. To characterize the temporal progress of soybean rust, disease severity data collected over time were fitted to nonlinear forms of the logistic and Gompertz models $(22,28)$ using the Marquardt's iterative method in the procedure NLIN of SAS (version 9.1.3; SAS Institute Inc., Cary, NC). The most suitable model for parameter estimation was determined using standardized residual plots, adjusted coefficients of determination, and asymptotic standard errors of estimates of initial disease severity and rates of disease progress (28). Estimates of the rate parameter $(r)$ and maximum disease severity $(K)$ derived from the model with the best fit were compared among planting dates by analysis of variance after fitting the best model to observed disease severity values for each replication of the planting dates. Mean values for $r$ and $K$ were then separated with Fisher's protected least significant difference (LSD) test at $\alpha=0.05$. The product $r K$, an overall measure of the absolute rate of disease increase (4), was calculated and used to compare disease progress among the different planting dates for TGx 1485-1D and TGx 1448-2E. The parameter $r$ is not an accurate measure of rate of disease progress if $K<1$ (28). In addition, disease severity values recorded over time for each planting date were used to calculate the area under the disease progress curve (AUDPC) as described by Campbell and Madden (4). Because planting date could have affected the length of epidemic duration due to difference in disease onset and length of cultivar maturity, the relative area under the disease progress curve (RAUDPC) was used to compare disease epidemics from different planting dates $(4,22)$.

The SAS procedure CORR was used to determine the physical variables that influenced the severity of soybean rust. For each soybean cultivar, correlation analyses were conducted separately for RAUDPC and urediniospore concentrations with the following weather variables: maximum, minimum, and mean air temperatures; RH; number of rainy days; rainfall; evaporation; and solar total radiation. The relationship among the above weather variables was also examined using correlation analysis.

The effects of planting date and cultivar on final disease severity, AUDPC, and RAUDPC were determined using analysis of variance using the GLM procedure of SAS and means separated using the LSD test at $\alpha=0.05$. In addition, a paired $t$ test was conducted in SAS using the procedure TTEST to determine the consistency in the reaction of both TGx 1485-1D and TGx 1448-2E to soybean rust (final disease severity and RAUDPC as response variables) and yield with respect to planting date. To examine the effect of disease severity (RAUDPC) on yield, linear regression analysis was conducted using the REG procedure of SAS for combined data for both cultivars across all planting seasons and separately for the wet and dry season data. 


\section{Results}

Weather variables. Rainfall amounts observed during the study period followed the expected bimodal pattern typical for the wet and dry seasons. Higher levels of total rainfall amounts $(>150 \mathrm{~mm})$ from germination to the last date of disease assessment (at R6 growth stage) were recorded for soybean planted between April and September in each year, while lower total rainfall amounts $(\leq 150 \mathrm{~mm})$ from germination to R6 were recorded for soybean planted in October to February in each year (Fig. 1A). The lowest and highest total rainfall recorded from germination to R6 was approximately $50 \mathrm{~mm}$ (26 November 2004) and $500 \mathrm{~mm}$ (4 April 2005), respectively. The trend in the number of rainy days (from germination to R6 growth stage) was similar to that of rainfall (Table 1), with total rainy days being higher in plantings conducted from April to September and lower for plantings from October to February (Fig. 1A). The trends in mean solar radiation and evaporation were very similar and were mirror images of rainfall amounts, with solar radiation and evaporation being higher during the plantings from October to March and lower in plantings conducted from April to August (Fig. 1B).

Maximum temperatures (from germination to R6) followed a distinct bimodal pattern similar to that of rainfall, with higher maximum temperatures $\left(>32^{\circ} \mathrm{C}\right)$ prevailing in plantings from October to February and lower maximum temperatures $\left(\leq 30^{\circ} \mathrm{C}\right)$ being observed for plantings from April to August (Fig. 1C). Unlike maximum temperatures, minimum temperatures varied just slightly and ranged between $21^{\circ} \mathrm{C}$ (31 May and 15 July 2005 and 25 September 2006) and $23^{\circ} \mathrm{C}$ (25 February 2005 and 12 January 2006). Generally, maximum RH did not vary much and was $>90 \%$ during the study period, except for one planting on 26 November 2004, when the maximum RH was $87 \%$ (Fig. 1C). Unlike maximum RH, variations in minimum $\mathrm{RH}$ were more pronounced, with high peaks $(>60 \%)$ for plantings from May to August and lower peaks $(<60 \%)$ for plantings from September to April (Fig. 1C). The mean RH was significantly $(P<0.05)$ positively correlated with rainfall and number of rainy days but significantly $(P<0.05)$ negatively correlated with the mean and maximum temperatures and evaporation (Table 1).

Disease severity and disease progress. Planting date and soybean cultivar significantly $(P<0.05)$ affected severity of soybean rust (Table 2). Cv. TGx 1485-1D had levels of disease severity consistently higher than TGx 1448-2E for all planting dates when soybean rust was present (Table 2). Across all planting dates, the highest final level of disease severity ( $74.5 \%$ for TGx $1485-1 \mathrm{D}$ and $44.8 \%$ for TGx 1448-2E) was observed on soybean planted on 10 August 2006, although similar levels of disease severity, albeit nonsignificant, were also observed for the planting dates of 13 October 2005 and 31 August 2004. No disease was observed on either cultivar for soybean planted on 14 January and 25 February 2005. In addition, no disease was observed on TGx 1448-2E for soybean planted on 24 February and 30 March 2006 (Table 2). Generally, disease severity was low on soybean planted from November to April the following year.

Although absolute means for disease severity were significantly different between planting dates, the temporal progress of soybean rust on both TGx 1485-1D and TGx 1448-2E was similar, and characteristic of a sigmoid curve (Fig. 2). To facilitate interpretation of results, disease progress curves were grouped into four groups based on the quartile distribution of RAUDPC for each planting date. For example, group I consisted of planting dates (February and March) that had either no disease or very low final levels of disease severity, while group IV consisted of planting dates (August and October) that had the highest mean levels of disease severity. Disease onset on soybean planted in August and October was about 14 days earlier on TGx 1485-1D than on TGx 1448-2E, while onset of disease for plantings in June and July was about 6 days earlier on TGx 1485-1D than on TGx 1448-2E (Fig. 2). For TGx 1485-1D, disease onset on soybean planted in August and October was 7 days earlier than soybean planted in June and
July and 24 days earlier than on soybean planted in November and January (Fig. 2A). For TGx 1448-2E, disease onset on soybean planted in August to October and in June and July was not different but was about 20 days earlier compared with soybean planted in November to January (Fig. 2B).

Temporal progress of soybean rust on TGx 1485-1D and TGx 1448-2E for all planting dates was best described by a nonlinear logistic model. Planting date and soybean cultivar significantly $(P$ $<0.05)$ affected rates of disease progress $(r)$, the upper asymptote $(K)$, and the absolute rates of disease increase, $r K$ (Table 3). Absolute rates of disease increase were significantly $(P<0.05)$ higher for TGx 1485-1D than for TGx 1448-2E, the highest $r K$ was observed on TGx 1485-1D planted on 25 September 2006, whereas the highest $r K$ on TGx 1448-2E was observed on plants planted on 11 October 2004. For TGx 1485-1D, higher absolute rates of disease increase $(r K>0.075)$ were generally observed on soybean planted between July and October, whereas low rates $(r K<0.045)$
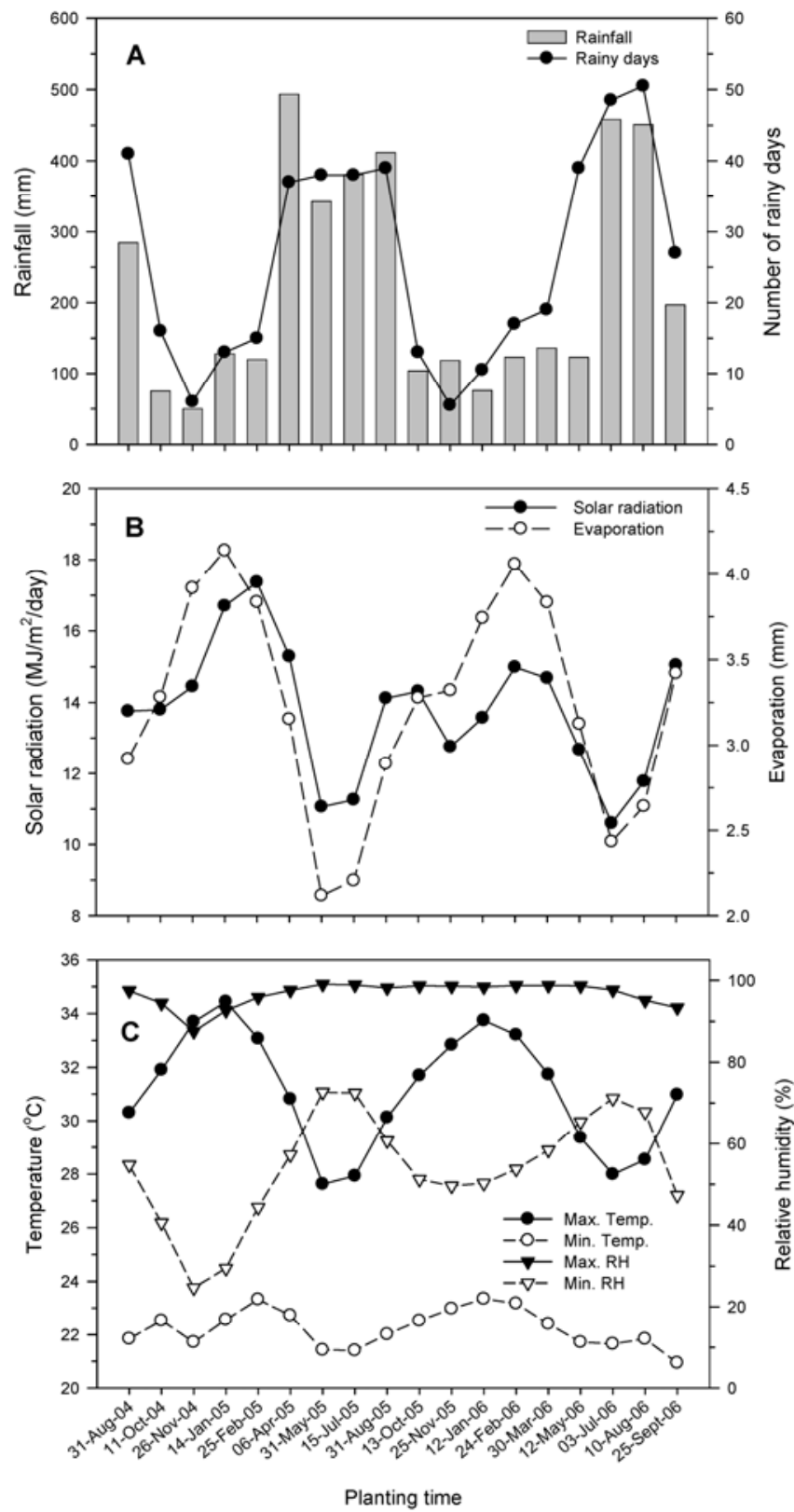

Fig. 1. A, Total rainfall and number of rainy days from germination to the last disease assessment date at growth stage (GS) R6; B, mean solar radiation and evaporation; and $\mathbf{C}$, minimum and maximum temperature and relative humidity from germination to GS R6, for each planting date from August 2004 to September 2006 in a field experiment to determine the effect of planting date on soybean rust severity in Nigeria. 
were observed on soybean planted between November and April (Table 3). Unlike TGx 1485-1D, higher $r K$ values $(>0.045)$ on TGx 1448-2E were observed on soybean planted between May and October (except for the planting on 12 May 2006), whereas lower $r K$ values $(<0.040)$ were observed when soybean were planted between November and April.

Inoculum and disease dynamics. Urediniospores of $P$. pachyrhizi were present in the air during the entire study period from August 2004 to September 2006 (Fig. 3). However, the relative number of spores varied across planting dates and was highest around July 2005 and lowest in February 2006. There was also a consistent seasonal pattern or trend in the observed number of spores and RAUDPC whereby both urediniospore concentrations and RAUDPC were higher from May to October and decreased from November to April the following year (Fig. 3).

Relationship between rust severity, spore concentration, and weather parameters. For both soybean cultivars, RAUDPC did not significantly $(P>0.05)$ correlate with rainfall amounts, number of rainy days, $\mathrm{RH}$, and minimum temperatures (Table 4). However, RAUDPC was significantly negatively correlated with evaporation $(r$ $=-0.73, P<0.01)$, solar radiation $(r=-0.60, P<0.05)$, and maximum and mean temperature $(r=-0.64, P<0.05)$ for TGx 1485-1D. Similar significant $(P<0.05)$ correlations between RAUDPC and evaporation, solar radiation, and maximum and mean temperatures were also observed for TGx 1448-2E (Table 4). For both cultivars, RAUDPC was significantly $(P<0.05)$ positively correlated $(r>$ $0.51)$ with urediniospore concentration.

The correlations between urediniospore concentrations and weather variables were very similar for both cultivars. For example, for TGx 1448-2E, urediniospore concentrations were significantly $(P<0.01)$ and negatively correlated with evaporation $(r=$ $-0.87)$, solar radiation $(r=-0.86)$, and all temperature variables (absolute $r>0.78)$. There were also significant $(P<0.05)$ correlations between urediniospore concentrations and number of rainy

Table 1. Pearson's correlation coefficients among weather variables recorded during a soybean rust field experiment conducted from August 2004 through November 2006 in Nigeria ${ }^{a}$

\begin{tabular}{|c|c|c|c|c|c|c|c|c|c|}
\hline \multirow[b]{2}{*}{ Parameter } & \multirow[b]{2}{*}{ Rainy days } & \multirow[b]{2}{*}{ Rainfall (mm) } & \multirow[b]{2}{*}{ Evap. $(\mathbf{m m})^{\mathrm{d}}$} & \multirow[b]{2}{*}{$\operatorname{Rad} .\left(\mathrm{MJ} / \mathrm{m}^{2} / \mathrm{day}\right)^{\mathrm{e}}$} & \multicolumn{3}{|c|}{ Temperature $\left({ }^{\circ} \mathbf{C}\right)^{\mathbf{b}}$} & \multicolumn{2}{|c|}{$\mathbf{R H}(\%)^{\mathrm{c}}$} \\
\hline & & & & & Min. & Max. & Mean & Min. & Max. \\
\hline Rainfall & $0.83 * * *$ & & $\cdots$ & $\ldots$ & $\cdots$ & $\cdots$ & $\cdots$ & $\cdots$ & $\ldots$ \\
\hline Evap. & $0.75^{* *}$ & $-0.68 * *$ & $\ldots$ & $\ldots$ & $\ldots$ & $\ldots$ & $\ldots$ & $\ldots$ & $\ldots$ \\
\hline Rad. & $-0.52 \mathrm{~ns}$ & $-0.38 \mathrm{~ns}$ & $0.83 * * *$ & $\ldots$ & $\ldots$ & $\ldots$ & $\ldots$ & $\ldots$ & $\ldots$ \\
\hline \multicolumn{10}{|l|}{ Temp. $\left({ }^{\circ} \mathrm{C}\right)$} \\
\hline Min. & $-0.61 *$ & $-0.39 \mathrm{~ns}$ & $0.72 * *$ & $0.72 * *$ & $\ldots$ & $\ldots$ & $\ldots$ & $\ldots$ & $\ldots$ \\
\hline Max. & $-0.86 * * *$ & $-0.71 * *$ & $0.96 * * *$ & $0.80 * * *$ & $0.73 * *$ & $\ldots$ & $\ldots$ & $\ldots$ & $\ldots$ \\
\hline Mean & $-0.84 * * *$ & $-0.66^{*}$ & $0.94 * * *$ & $0.82 * * *$ & $0.83 * * *$ & $0.99 * * *$ & $\ldots$ & $\ldots$ & $\ldots$ \\
\hline \multicolumn{10}{|l|}{$\mathrm{RH}(\%)$} \\
\hline Min. & $0.80 * * *$ & $0.69 * *$ & $-0.83 * * *$ & $-0.70 * *$ & $-0.44 \mathrm{~ns}$ & $-0.91 * * *$ & $-0.84 * * *$ & $\ldots$ & $\ldots$ \\
\hline Max. & $0.41 \mathrm{~ns}$ & $0.36 \mathrm{~ns}$ & $-0.49 \mathrm{~ns}$ & $-0.35 \mathrm{~ns}$ & $0.06 \mathrm{~ns}$ & $-0.52 \mathrm{~ns}$ & $-0.41 \mathrm{~ns}$ & $0.78 * * *$ & $\ldots$ \\
\hline Mean & $0.75 * *$ & $0.65^{*}$ & $-0.80 * * *$ & $-0.66 *$ & $-0.36 \mathrm{~ns}$ & $-0.87 * * *$ & $-0.79 * * *$ & $0.99 * * *$ & $0.85 * * *$ \\
\hline
\end{tabular}

a Asterisks $*, * *$, and $* * *$ indicate significant correlations at $P=0.05,0.01$, and 0.001 , respectively; $\mathrm{ns}=$ nonsignificant.

${ }^{\mathrm{b}}$ Mean, minimum (Min.), and maximum (Max.) temperatures.

${ }^{\mathrm{c}}$ Relative humidity.

${ }^{\mathrm{d}}$ Evaporation.

e Solar radiation.

Table 2. Soybean rust severity on soybean cvs. TGx 1485-1D and TGx 1448-2E, infected with Phakopsora pachyrhizi in the field from August 2004 and November 2006 in Nigeria

\begin{tabular}{|c|c|c|c|c|c|c|}
\hline \multirow[b]{2}{*}{ Year, planting date } & \multicolumn{3}{|c|}{ TGx 1485-1D } & \multicolumn{3}{|c|}{ TGx 1448-2E } \\
\hline & $\operatorname{FDS}(\%)^{\mathrm{a}}$ & $\mathbf{A U D P C}^{\mathbf{b}}$ & RAUDPC $^{\mathbf{b}}$ & FDS (\%) & AUDPC & RAUDPC \\
\hline \multicolumn{7}{|l|}{2004} \\
\hline 31 August & 69.8 & $1,395.6$ & 24.9 & 43.3 & 933.3 & 15.1 \\
\hline 11 October & 61.6 & $1,146.3$ & 20.5 & 42.7 & 841.9 & 13.6 \\
\hline 26 November & 21.3 & 328.1 & 5.9 & 13.3 & 149.0 & 2.4 \\
\hline \multicolumn{7}{|l|}{2005} \\
\hline 14 January & 0.0 & 0.0 & 0.0 & 0.0 & 0.0 & 0.0 \\
\hline 25 February & 0.0 & 0.0 & 0.0 & 0.0 & 0.0 & 0.0 \\
\hline 6 April & 7.1 & 80.5 & 1.4 & 2.5 & 19.5 & 0.3 \\
\hline 31 May & 63.7 & $1,125.8$ & 20.1 & 31.5 & 550.8 & 8.9 \\
\hline 15 July & 61.0 & $1,080.1$ & 19.3 & 34.4 & 647.2 & 10.4 \\
\hline 31 August & 60.3 & $1,536.3$ & 27.4 & 42.0 & 881.2 & 14.2 \\
\hline 13 October & 70.1 & $1,424.2$ & 25.4 & 43.6 & 874.1 & 14.1 \\
\hline 25 November & 31.8 & 501.6 & 9.0 & 17.7 & 287.2 & 4.6 \\
\hline \multicolumn{7}{|l|}{2006} \\
\hline 12 January & 10.0 & 120.3 & 2.1 & 3.8 & 38.7 & 0.6 \\
\hline 24 February & 2.0 & 16.0 & 0.3 & 0.0 & 0.0 & 0.0 \\
\hline $30 \mathrm{March}$ & 0.8 & 6.9 & 0.1 & 0.0 & 0.0 & 0.0 \\
\hline 12 May & 15.0 & 243.6 & 4.4 & 10.3 & 147.6 & 2.4 \\
\hline 3 July & 51.7 & 964.4 & 17.2 & 31.2 & 570.0 & 9.2 \\
\hline 10 August & 74.5 & $1,418.2$ & 25.3 & 44.8 & 940.6 & 15.2 \\
\hline 25 September & 65.3 & $1,245.4$ & 22.2 & 39.7 & 834.6 & 13.5 \\
\hline $\mathrm{LSD}^{\mathrm{c}}$ & 3.7 & 89.3 & 1.5 & 4.4 & 53.6 & 1.0 \\
\hline
\end{tabular}

${ }^{a}$ Final disease severity (FDS) was recorded when plants were at R6 growth stage (approximately 76 and 84 days after germination for TGx 1485-1D and TGx 1448-2E, respectively). TGx 1485-1D is early-maturing and highly susceptible to soybean rust, while TGx 1448-2E is late-maturing and moderately susceptible to soybean rust.

${ }^{\mathrm{b}}$ AUDPC $=$ area under disease progress curve; RAUDPC $=$ relative AUDPC obtained by dividing the AUDPC by the total number of days between the first and last date of disease assessment.

${ }^{\mathrm{c}}$ Fisher's protected least significant difference test at $\alpha=0.05$. 
days $(r=-0.701)$, and minimum and mean RH $(r=0.73$ and 0.70 , respectively). However, no significant correlations were observed between urediniospore concentrations and either rainfall or maximum RH (Table 4).

Planting date and soybean yields. Planting date and cultivar significantly $(P<0.05)$ affected soybean yields (Table 5$)$. Across planting dates, TGx $1448-2 \mathrm{E}$ had significantly $(P<0.05)$ higher yields than TGx 1485-1D. In addition, planting date consistently affected soybean yields regardless of the cultivar, with the highest yields being observed for soybean planted on 31 May 2005 and 3 July 2006 (Table 5). In general, soybean planted in May through August or October (for TGx 1448-2E) had significantly higher yields than soybean planted between November and April (Table 5). Yield for all the planting dates (wet and dry seasons) for TGx 1485-1D and TGx 1448-2E did not indicate any meaningful correlation between RAUDPC and yield (data not shown). However, when data were restricted to only the wet season in all 3 years, RAUDPC significantly $(P<0.001)$ affected yield, with an increase in RAUDPC resulting in a linear decrease in yield (Fig. 4).

\section{Discussion}

In this study, soybean cultivars with different levels of susceptibility to $P$. pachyrhizi and having different physiological maturity periods were sequentially planted over a period of 3 years to generate seasonal windows that were different in weather, plant conditions, and rust epidemics. Temporal dynamics of soybean rust in relation to weather were quantified and the effect of planting date on disease severity was established. Disease severity increased logistically, as is typical of polycyclic epidemics such as soybean rust, and disease onset was earlier on an early-maturing, highly susceptible soybean cultivar than on a late-maturing, less susceptible cultivar. Furthermore, although planting during the dry season resulted in lower levels of infection than planting during the wet season, disease severity from sequential plantings within each season consistently varied from one month to the next, indicating that selection of planting date can provide a useful cultural control for reducing soybean rust severity in Nigeria.

In the presence of soybean rust within a given planting date, disease resistance in the two soybean cultivars was expressed as lower RAUDPC, $r K$, and $Y_{\mathrm{o}}$ (initial disease severity) values. For example, $r K$ and RAUDPC values for the moderately susceptible and latematuring TGx 1448-2E were 40 and 50\%, respectively, lower than corresponding values for the highly susceptible and early-maturing TGx 1485-1D in plantings in July, August, and October in 2005. Similar observations in AUDPC and infection rates due to $P$. pachyrhizi infection of susceptible and tolerant soybean genotypes were also reported in Taiwan (13). In a study to quantify development of soybean rust in Taiwan, Tschanz and Wang (36) concluded that the lower rates of disease development on the resistant cv. G8587 was also an indication of general resistance. Thus, although no genetic studies have been conducted on the two cultivars used in this study, differences in the observed infection rates and disease severity may be explained, in part, by the inherent nature of cultivar resistance to infection by $P$. pachyrhizi $(29,37)$ and differences in host maturity (39). Within a given planting date, disease onset was earlier on the susceptible TGx 1485-1D than on the moderately susceptible TGx 1448-2E. The consistent response of the two cultivars to soybean rust with respect to RAUDPC, $r K$, and $Y_{\mathrm{o}}$ suggests that these three tools for quantifying disease resistance may be controlled by the same genetic factors (16).

Planting date consistently affected soybean rust severity regardless of the test cultivar. Specifically, higher levels of disease severity were observed on soybean planted from July to October than soybean planted from November to April. The effect of planting date on disease severity can be explained by a combination of several factors. First, the amount of urediniospores present during the period between November and April was approximately four times lower than spore concentrations between July and October. Thus, in a variety of ceteris paribus conditions, infection is likely to be higher from July to October than from November and April. Sec- ond, the lower maximum temperatures from July to October may also have promoted disease development (20). The minimum temperatures observed in this study were comparatively similar across planting dates (range of 21 to $23^{\circ} \mathrm{C}$ ) and were within the range required for infection by $P$. pachyrhizi (21). However, the maximum temperatures from July to October and November to April were $<30^{\circ} \mathrm{C}$ and $>30^{\circ} \mathrm{C}$, respectively. Field temperatures of $>30^{\circ} \mathrm{C}$ have been reported to retard the development of soybean rust (5). Frequent precipitation combined with long periods of leaf wetness may also have contributed to high levels of disease from July to October, during which there was a higher number of rainy days and reduced evaporation compared with planting dates between November and April. An increase in the duration of leaf wetness promotes infection by $P$. pachyrhizi and development of soybean rust (27). This increase in leaf wetness duration can be due to either increased frequency of precipitation or reduced evaporation of available moisture on the leaf surface.

One of the objectives of this study was to determine the extent to which staggering of planting date can be used to reduce soybean rust severity. Although differences in rust severity were observed between the wet and dry seasons, significant differences in disease severity were also evident within each cropping season. The low disease severity and yields observed during the dry season most likely were due to the direct and indirect effects of evapotranspiration. For optimal productivity, high rates of crop evapotranspiration need to be offset by a corresponding availability of adequate mois-
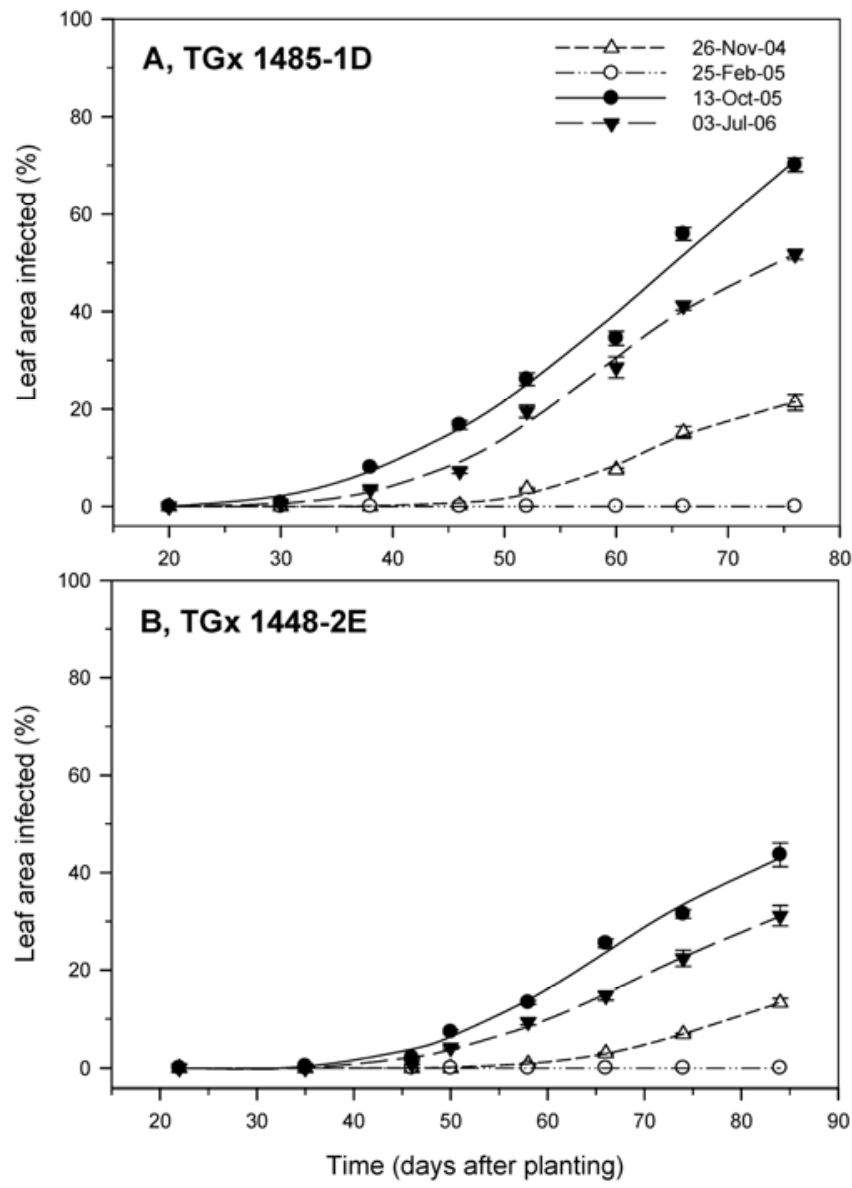

Fig. 2. Disease progress curves for soybean rust on soybean cultivars $A, T G x$ 1485-1D (early-maturing and highly susceptible) and B, TGx 1448-2E (latematuring and moderately susceptible) in a field experiment planted from August 2004 to September 2006 to determine the effect of planting date on soybean rust severity in Nigeria. Data points are mean disease severity values, vertical bars represent standard errors of the mean observed disease values, and curves are the predicted disease severity values obtained from fitting a nonlinear logistic model to observed data. Depicted planting dates are selected to illustrate the range of disease progress curves observed during the entire study. 
Table 3. Results of nonlinear regression analysis of temporal progress of soybean rust (Phakopsora pachyrhizi) on soybean cvs. TGx 1485-1D and TGx 1448-2E, obtained using logistic model ${ }^{\mathrm{a}}$

\begin{tabular}{|c|c|c|c|c|c|c|c|c|c|c|}
\hline \multirow[b]{2}{*}{ Year, planting date } & \multicolumn{5}{|c|}{ TGx 1485-1D } & \multicolumn{5}{|c|}{ TGx 1448-2E } \\
\hline & Rate $(r)$ & SE for $r$ & $\boldsymbol{K}$ & SE for $K$ & $r K$ & $r$ & SE for $r$ & $\boldsymbol{K}$ & SE for $K$ & $r K$ \\
\hline \multicolumn{11}{|l|}{2004} \\
\hline 31 August & 0.098 & 0.012 & 0.844 & 0.081 & 0.083 & 0.098 & 0.017 & 0.515 & 0.061 & 0.050 \\
\hline 11 October & 0.146 & 0.006 & 0.661 & 0.013 & 0.098 & 0.134 & 0.015 & 0.457 & 0.026 & 0.061 \\
\hline 26 November & 0.188 & 0.024 & 0.233 & 0.014 & 0.044 & 0.155 & 0.010 & 0.176 & 0.010 & 0.027 \\
\hline \multicolumn{11}{|l|}{2005} \\
\hline 14 January & $\ldots$ & $\ldots$ & $\ldots$ & $\ldots$ & $\ldots$ & $\ldots$ & $\ldots$ & $\ldots$ & $\ldots$ & $\ldots$ \\
\hline 25 February & & $\ldots$ & $\ldots$ & $\ldots$ & $\ldots$ & $\ldots$ & $\ldots$ & $\ldots$ & $\ldots$ & $\ldots$ \\
\hline 6 April & 0.211 & 0.037 & 0.106 & 0.013 & 0.023 & 0.172 & 0.002 & 0.214 & 0.002 & 0.037 \\
\hline 31 May & 0.131 & 0.019 & 0.734 & 0.069 & 0.097 & 0.138 & 0.014 & 0.360 & 0.021 & 0.050 \\
\hline 15 July & 0.120 & 0.021 & 0.737 & 0.093 & 0.090 & 0.130 & 0.013 & 0.392 & 0.025 & 0.051 \\
\hline 31 August & 0.111 & 0.012 & 0.644 & 0.036 & 0.072 & 0.084 & 0.020 & 0.551 & 0.120 & 0.046 \\
\hline 13 October & 0.098 & 0.017 & 0.887 & 0.130 & 0.087 & 0.115 & 0.017 & 0.491 & 0.045 & 0.057 \\
\hline 25 November & 0.095 & 0.038 & 0.445 & 0.196 & 0.043 & 0.154 & 0.013 & 0.197 & 0.009 & 0.030 \\
\hline \multicolumn{11}{|l|}{2006} \\
\hline 12 January & $\ldots$ & $\ldots$ & $\ldots$ & $\ldots$ & $\ldots$ & 0.129 & 0.028 & 0.223 & 0.015 & 0.029 \\
\hline 24 February & $\ldots$ & $\ldots$ & $\ldots$ & $\ldots$ & $\ldots$ & $\ldots$ & $\ldots$ & $\ldots$ & $\ldots$ & $\ldots$ \\
\hline 30 March & & & & & & & & & & \\
\hline 12 May & 0.154 & 0.014 & 0.167 & 0.008 & 0.026 & 0.135 & 0.013 & 0.127 & 0.009 & 0.017 \\
\hline 3 July & 0.128 & 0.015 & 0.577 & 0.040 & 0.075 & 0.111 & 0.015 & 0.371 & 0.036 & 0.041 \\
\hline 10 August & 0.093 & 0.014 & 0.976 & 0.136 & 0.089 & 0.110 & 0.010 & 0.522 & 0.310 & 0.057 \\
\hline 25 September & 0.140 & 0.009 & 0.704 & 0.021 & 0.100 & 0.093 & 0.014 & 0.496 & 0.062 & 0.046 \\
\hline $\mathrm{LSD}^{\mathrm{b}}$ & 0.021 & $\ldots$ & 0.100 & $\ldots$ & 0.009 & 0.022 & $\ldots$ & 0.023 & $\ldots$ & 0.043 \\
\hline
\end{tabular}

${ }^{a} \mathrm{Cv}$. TGx 1485-1D is early-maturing and highly susceptible to soybean rust, while TGx 1448-2E is late-maturing and moderately susceptible to soybean rust. Disease severity was expressed as leaf area infected (proportion) on an entire plant. $\mathrm{SE}=$ standard error; $K=$ upper asymptote; $r K=$ absolute rate; $\ldots=$ model did not generate parameter values due to lack of convergence.

${ }^{\mathrm{b}}$ Fisher's protected least significant difference (LSD) test at $\alpha=0.05$.

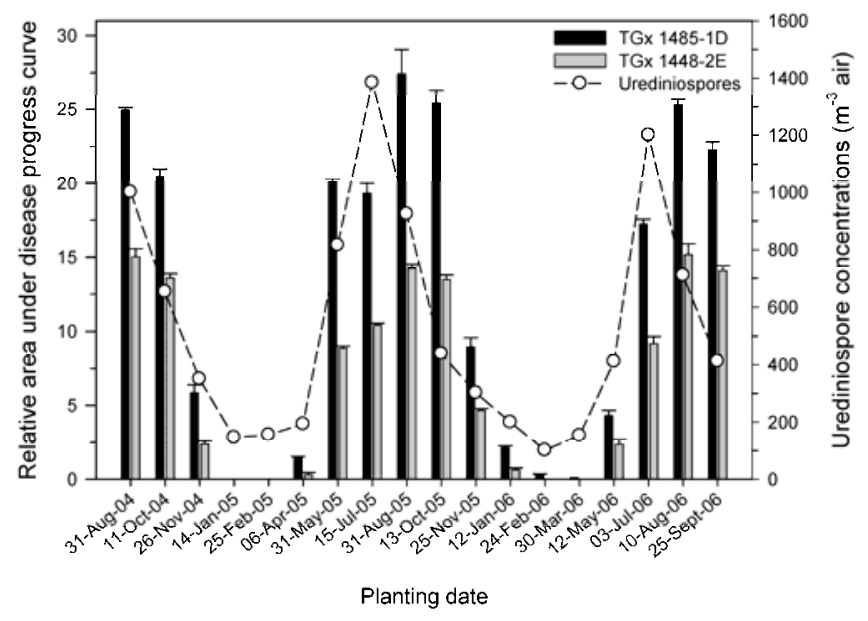

Fig. 3. Relative area under disease progress curve (RAUDPC) for soybean cvs. TGx 1485-1D and TGx 1448-2E, and urediniospore concentration in a field experiment planted from August 2004 to September 2006 to determine the effect of planting date on soybean rust severity. TGx $1485-1 \mathrm{D}$ is early-maturing and highly susceptible to soybean rust, while TGx $1448-2 E$ is late-maturing and moderately susceptible to soybean rust. Whiskers are standard errors of the mean values for RAUDPC.

ture (17). However, moisture was limited during the dry season because the irrigation capacity was not able to supply all the soil moisture needed for normal growth. Because P. pachyrhizi is an obligate pathogen, any variable that limits crop growth will also affect disease severity. This low level of disease coupled with low yields was perhaps the main reason for the lack of correlation between yield and disease severity when analysis was based on combined wet- and dry-season data. Indeed, a significant effect of disease on yield became more apparent when only data from wet season was considered. Thus, the use of planting date to reduce disease may only be practical during the wet season. During the wet season, soybean planted between May and July had significantly lower RAUDPC values than soybean planted between $\mathrm{Au}-$ gust and October, regardless of the test cultivars. Yields for soybean planted between May and July were also comparable or even higher than for soybean planted between August and October, regardless of the test cultivar. In southwestern Nigeria, soybean is relay cropped with cassava and maize from May to October (1). In these areas, farmers plant two soybean crops a year, the first crop during May and the second crop during September or October, often in the same field. However, after the introduction of rust, farmers abandoned the second planting because rust inoculum from the first planting often devastated the second crop. In several pathosystems, early or late planting within a growing season has also been shown to greatly influence plant disease development $(24,30)$. Results from this study suggests that planting early within the wet season (i.e., May or June) can substantially reduce severity of soybean rust without a substantial yield penalty. Based on these considerations, selection of planting date may provide a useful cultural control for reducing severity of soybean rust in Nigeria and in West African countries with similar weather and cropping patterns. In Taiwan, planting soybean in the summer has been shown to delay the onset of soybean rust compared with planting in spring or autumn (3). It was suggested that physiological age of the soybean plant was responsible for the difference in disease severity between summer versus spring or autumn planting $(35,40)$. In this study, we did not examine the influence of maturity duration of the soybean cultivars on differences in rust severity during the wet and dry season and we recommend further studies to establish whether such a phenomenon plays a role in suppression of soybean rust in tropical climates of West Africa.

Several studies $(5,20,23,27)$ have been conducted to determine the important physical factors that influence infection by $P$. pachyrhizi and development of soybean rust. Our results are in agreement with previous studies where temperature, duration of leaf wetness, and solar radiation were reported to affect soybean rust severity. However, we did not observe a significant correlation between rainfall amount and number of rainy days with disease severity. A similar lack of influence of rainfall on soybean rust has also been reported in Uganda (19), where rainfall did not influence rust severity prior or after the mid-growth period of soybean. In Taiwan, a study to determine the effect of rainfall on rust development in three planting dates over 2 years showed that the timing of the first rain and the amount of rainfall during the season were key 
Table 4. Pearson's correlation coefficients among weather variables and relative area under disease progress curve (RAUDPC) for soybean cvs. TGx 1485$1 \mathrm{D}$ and TGx 1448-2E, and urediniospore concentration in the field from August 2004 to November 2006 in Nigeria ${ }^{\mathrm{a}}$

\begin{tabular}{|c|c|c|c|c|}
\hline \multirow[b]{2}{*}{ Variable } & \multicolumn{2}{|c|}{ RAUDPC } & \multicolumn{2}{|c|}{ Urediniospore concentration (per $\mathbf{m}^{3}$ of air) } \\
\hline & TGx 1485-1D & TGx 1448-2E & TGx 1485-1D & TGx 1448-2E \\
\hline Rainy days & $0.399 \mathrm{~ns}$ & $0.380 \mathrm{~ns}$ & $0.644 *$ & $0.701 *$ \\
\hline Rainfall (mm) & $0.366 \mathrm{~ns}$ & $0.326 \mathrm{~ns}$ & $0.428 \mathrm{~ns}$ & $0.481 \mathrm{~ns}$ \\
\hline Evaporation (mm) & $-0.726^{* *}$ & $-0.629 * *$ & $-0.850 * *$ & $-0.868 * *$ \\
\hline Solar radiation $\left(\mathrm{MJ} / \mathrm{m}^{2} /\right.$ day $)$ & $-0.595^{*}$ & $-0.571^{*}$ & $-0.846^{* *}$ & $-0.855^{* *}$ \\
\hline Minimum temperature & $-0.457 \mathrm{~ns}$ & $-0.453 \mathrm{~ns}$ & $-0.671 *$ & $-0.783 * *$ \\
\hline Maximum temperature & $-0.646^{*}$ & $-0.549 *$ & $-0.839 * *$ & $-0.842 * *$ \\
\hline Mean temperature $\left({ }^{\circ} \mathrm{C}\right)$ & $-0.644^{*}$ & $-0.550 *$ & $-0.880 * * *$ & $-0.881 * * *$ \\
\hline Minimum relative humidity $(\%)$ & $0.489 \mathrm{~ns}$ & $0.402 \mathrm{~ns}$ & $0.725^{*}$ & $0.731 *$ \\
\hline Maximum relative humidity $(\%)$ & $0.258 \mathrm{~ns}$ & $0.202 \mathrm{~ns}$ & $0.506 \mathrm{~ns}$ & $0.521 \mathrm{~ns}$ \\
\hline Mean relative humidity $(\%)$ & $0.463 \mathrm{~ns}$ & $0.376 \mathrm{~ns}$ & $0.697 *$ & $0.703 *$ \\
\hline Urediniospore concentration (per $\mathrm{m}^{3}$ of air) & $0.585 *$ & $0.512 *$ & $\ldots$ & $\ldots$ \\
\hline
\end{tabular}

a TGx 1485-1D is early-maturing and highly susceptible to soybean rust, while TGx 1448-2E is late-maturing and moderately susceptible to soybean rust. Asterisks $* * *$, and $* * *$ indicate significant correlations at $P=0.05,0.01$, and 0.001 , respectively; ns $=$ nonsignificant.

Table 5. Yields for soybean cvs. TGx 1485-1D and TGx 1448-2E planted in the field from August 2004 to September 2006 to determine the effect of planting date on soybean rust severity in Nigeria ${ }^{a}$

\begin{tabular}{|c|c|c|c|c|}
\hline \multirow{2}{*}{$\begin{array}{l}\text { Year, } \\
\text { planting date }\end{array}$} & \multicolumn{2}{|c|}{ TGx 1485-1D } & \multicolumn{2}{|c|}{ TGx 1448-2E } \\
\hline & Yield (ton/ha) & SE & Yield (ton/ha) & SE \\
\hline \multicolumn{5}{|l|}{2004} \\
\hline $31 \mathrm{Aug}$ & 0.9 & 0.17 & 1.3 & 0.19 \\
\hline $11 \mathrm{Oct}$ & 0.8 & 0.15 & 1.2 & 0.15 \\
\hline 26 Nov & 0.4 & 0.09 & 0.6 & 0.12 \\
\hline \multicolumn{5}{|l|}{2005} \\
\hline 14 Jan & 0.1 & 0.03 & 0.3 & 0.03 \\
\hline $25 \mathrm{Feb}$ & 0.1 & 0.03 & 0.4 & 0.03 \\
\hline $6 \mathrm{Apr}$ & 0.2 & 0.03 & 0.8 & 0.17 \\
\hline 31 May & 1.1 & 0.12 & 1.6 & 0.17 \\
\hline 15 July & 0.9 & 0.17 & 1.4 & 0.21 \\
\hline $31 \mathrm{Aug}$ & 0.7 & 0.12 & 1.2 & 0.06 \\
\hline $13 \mathrm{Oct}$ & 0.5 & 0.07 & 0.8 & 0.21 \\
\hline $25 \mathrm{Nov}$ & 0.4 & 0.09 & 0.6 & 0.17 \\
\hline \multicolumn{5}{|l|}{2006} \\
\hline 12 Jan & 0.2 & 0.00 & 0.3 & 0.03 \\
\hline $24 \mathrm{Feb}$ & 0.2 & 0.03 & 0.2 & 0.03 \\
\hline $30 \mathrm{Mar}$ & 0.6 & 0.03 & 0.3 & 0.06 \\
\hline 12 May & 1.2 & 0.09 & 1.3 & 0.09 \\
\hline 3 July & 1.2 & 0.15 & 1.7 & 0.15 \\
\hline $10 \mathrm{Aug}$ & 0.8 & 0.09 & 1.3 & 0.07 \\
\hline $25 \mathrm{Sep}$ & 0.5 & 0.03 & 1.1 & 0.22 \\
\hline $\operatorname{LSD}(\alpha=0.05)^{\mathrm{b}}$ & 0.3 & $\ldots$ & 0.4 & $\ldots$ \\
\hline
\end{tabular}

a TGx $1485-1 \mathrm{D}$ is early-maturing and highly susceptible to soybean rust, while TGx 1448-2E is late-maturing and moderately susceptible to soybean rust. $\mathrm{SE}=$ standard error.

b Fisher's protected least significant difference test.

factors affecting development soybean rust epidemics (35). In another study, Del Ponte et al. (7) improved the correlation between rainfall and soybean rust severity by using only accumulated rainfall for a 30-day window following disease detection. The number of rainy days over the same 30-day window following disease detection also was a good predictor of maximum disease severity (7). Thus, our inability to detect a significant correlation between disease severity and rainfall could be related to, besides other factors, the larger temporal window (approximately 55 to 62 days) for which the two variables were examined. Although it appears that rainfall is a variable that promotes rust epidemics in the field, the direct or indirect biological role of rain in the epidemic process is still not well established (6). RH (>80\%) has been reported to be necessary for infection (21) but we did not observe a significant relationship between disease severity and RH. Rather, we observed a significant positive correlation between $\mathrm{RH}$ and urediniospore concentration. It has been suggested that RH may affect the timing of spore release and spore survival (15) but quantitative information is still lacking. Although the effects of irrigation on the correlation between moisture variables and soybean rust severity were not evaluated in this study, it is unlikely that irrigation could have

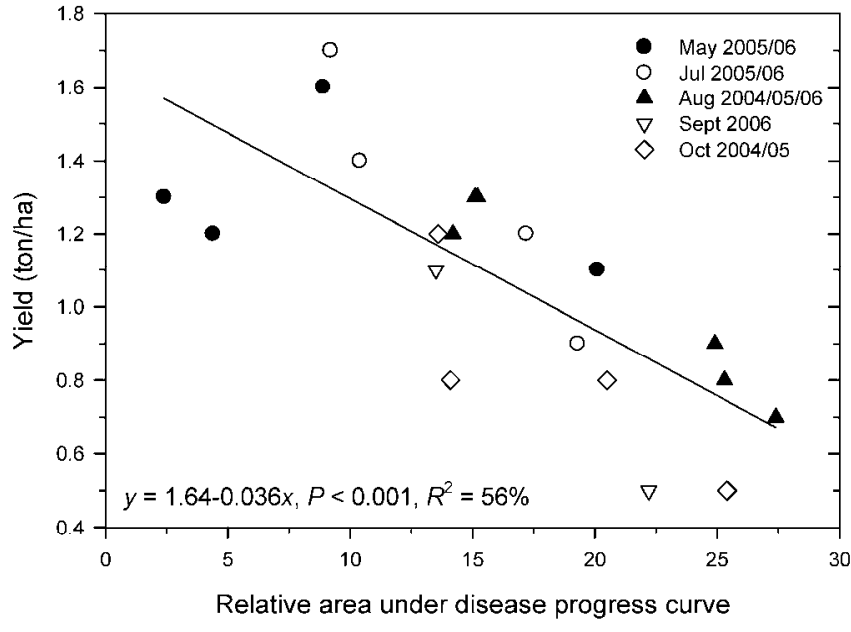

Fig. 4. Relationship between soybean yield and relative area under disease progress (\%-disease days) during the wet seasons in 2004, 2005, and 2006 in Nigeria in an experiment conducted to determine the effect of planting date on the epidemics soybean rust caused by Phakopsora pachyrhizi. Data shown are for combined disease and yield data for soybean cvs. TGx 1485-1D (early-maturing and highly susceptible) and TGx 1448-2E (late-maturing and moderately susceptible)

had an impact on the results presented here for a couple of reasons. First, irrigation was applied during the dry season mainly to ensure survival of the crop during the experimental period. Second, the dry season was characterized by high evaporation rates, and soybean rust was either absent or very minimal during this season. The high evaporation rates suggest that the effects of irrigation during the dry season would be very short-lived to meaningfully affect disease severity by either increasing the $\mathrm{RH}$ or prolonging leaf wetness.

This study examined the effect of planting date on soybean rust severity and provided a basis for selecting the planting date within the wet season to reduce disease severity. Further, we determined the key weather variables that influence disease development and availability of urediniospore during the season. Information on the effect of meteorological factors on epidemiological and aerobiological components of soybean rust can be expressed in the form of mathematical functions or rules that use single or combined factors as predictor variables. Several soybean rust forecasting systems use such information individually or integrated to predict the risks in real time during the season or assess the risks of the disease under different climatic scenarios (31). However, due to differences in weather patterns and disease dynamics, prediction systems developed, for example, based on meteorological variables in China or the United States will not necessarily be accurate predictors for the disease in West Africa (6). Thus, information generated from this study provides a working framework for developing 
similar prediction systems for the risk of soybean rust development in West Africa, where predictors for the disease have not yet been developed or explored.

\section{Literature Cited}

1. Adeniyan, O. N., and Ayoola, O. T. 2007. Evaluation of four improved soybean varieties under different planting dates in relayed cropping system with maize under soybean/maize/cassava intercrop. Afr. J. Biotechnol. 6:2220-2224

2. Akinsanmi, O. A., Ladipo, J. L., and Oyekan, P. O. 2001. First report of soybean rust (Phakopsora pachyrhizi) in Nigeria. Plant Dis. 85:97.

3. Bromfield, K. R. 1984. Soybean Rust. Monogr. No. 11. American Phytopathological Society, St. Paul, MN.

4. Campbell, C. L., and Madden, L. V. 1990. Introduction to Plant Disease Epidemiology. John Wiley and Sons, New York.

5. Casey, P. S. 1981. The epidemiology of soybean rust: Phakopsora pachyrhizi Syd. Soybean Rust Newsl. 4:3-5.

6. Del Ponte, E. M., and Esker, P. D. 2008. Meteorological factors and Asian soybean rust epidemics - a systems approach and implications for risk assessment. Sci. Agric. 65:88-97.

7. Del Ponte, E. M., Godoy, C. V., Li, X., and Yang, X. B. 2006. Predicting severity of Asian soybean rust epidemics with empirical rainfall models. Phytopathology 96:797-803.

8. Dugje, I. Y., Omoigui, L. O., Ekeleme, F., Bandyopadhyay, R., Lava Kumar, P., and Kamara, A. Y. 2009. Farmers' Guide to Soybean Production in Northern Nigeria, International Institute of Tropical Agriculture, Ibadan, Nigeria.

9. FAO. 2006. Food and Agricultural Organization. http://faostat.fao.org.

10. Fehr, W. R., Caviness, C. E., Burmood, D. T., and Pennington, J. S. 1971. Stage of development descriptions for soybeans, Glycine max (L.) Merrill. Crop Sci. 11:929-931.

11. Grant-Smith, E. 1986. Sampling and Identifying Allergenic Pollens and Molds. An Illustrated Identification Manual for Air Samplers. Vol. II. Blewstone Press, San Antonio, TX.

12. Hartman, G. L., Miles, M. R., and Frederick, R. D. 2005. Breeding for resistance to soybean rust. Plant Dis. 89:664-666.

13. Hartman, G. L., Wang, T. C., and Tschanz, A. T. 1991. Soybean rust development and the quantitative relationship between rust severity and soybean yields. Plant Dis. 75:596-600.

14. Hennings, V. P. 1903. A few new Japanese Uredinaceae. Hedwigia 42:S107108

15. Isard, S. A., Gage, S. H., Comtois, P., and Russo, J. M. 2005. Principles of the atmospheric pathway for invasive species applied to soybean rust. BioScience 55:851-861.

16. Johnson, C. S., Beute, M. K., and Ricker, M. D. 1986. Relationship between components of resistance and disease progress of early leaf spot on virginia type peanut. Phytopathology 76:495-499.

17. Kashyap, P. S., and Panda, R. K. 2001. Evaluation of evapotranspiration estimation methods and development of crop-coefficients for potato crop in a sub-humid region. Agric. Water Manage. 50:9-25.

18. Kawuki, R. S., Adipala, E., Lamo, J., and Tukamuhabwa, P. 2003. Responding to the soybean rust epidemic in sub-Saharan Africa: a review. Afr. Crop. Sci. J. 11:301-318.

19. Kawuki, R. S., Tukamuhabwa, P., and Adipala, E. 2004. Soybean rust severity, rate of rust development, and tolerance as influenced by maturity period and season. Crop Prot. 23:447-455.

20. Kochman, J. K. 1979. The effect of temperature on development of soybean rust (Phakopsora pachyrhizi). Aust. J. Agric. Res. 30:273-277.
21. Levy, C. 2005. Epidemiology and chemical control of soybean rust in Southern Africa. Plant Dis. 89:669-774.

22. Madden, L V., Hughes, G., and van den Bosch, F. 2007. The Study of Plant Disease Epidemics. American Phytopathological Society, St. Paul, MN.

23. Marchetti, M. A., Melching, J. S., and Bromfield, K. R. 1976. The effects of temperature and dew period on germination and infection by uredospores of Phakopsora pachyrhizi. Phytopathology 66:461-463.

24. Matheron, M. E., McCreight, J. D., Tickes, B. R., and Porchas, M. 2005. Effect of planting date, cultivar, and stage of plant development on incidence of Fusarium wilt of lettuce in desert production fields. Plant Dis. 89:565-570.

25. Miles, M. R., Levy, C., Morel, W., Mueller, T., Steinlage, T., van Rij, N., Frederick, R. D., and Hartman, G. L. 2007. International fungicide efficacy trials for the management of soybean rust. Plant Dis. 91:1450-1458.

26. Mueller, T. A., Miles, M. R., Morel, W., Marios, J. J., Wright, D. L., Kemerait, R. C., Levy, C., and Hartman, G. L. 2009. Effect of fungicide and timing of application on soybean rust severity and yield. Plant Dis. 93:243248.

27. Narváez, D. F., Jurick, W. M., II, Marois, J. J., and Wright, D. L. 2010. Effects of surface wetness periods on development of soybean rust under field conditions. Plant Dis. 94:258-264.

28. Neher, D. A., and Campbell, C. L. 1997. Analysis of disease progress curves using nonlinear models. Pages 38-41 in: Exercises in Plant Disease Epidemiology. L. J. Francl and D. A. Neher, eds. American Phytopathological Society, St. Paul, MN.

29. Oloka, H. K., Tukamuhabwa, P., Sengooba, T., and Shanmugasundram, S 2008. Reaction of exotic soybean germplasm to Phakopsora pachyrhizi in Uganda. Plant Dis. 92:1493-1496.

30. Pfender, W. F. 2004. Effect of autumn planting date and stand age on severity of stem rust in seed crops of perennial ryegrass. Plant Dis. 88:10171020.

31. Pivonia, S., and Yang, X. B. 2004. Assessment of the potential year-round establishment of soybean rust throughout the world. Plant Dis. 88:523-529.

32. Sinclair, J. B., and Hartman, G. L. 1999. Soybean Rust. Pages 25-26 in: Compendium of Soybean Diseases. G. L. Hartman, J. B. Sinclair, and J. C. Rupe, eds. American Phytopathological Society, St. Paul, MN.

33. Tefera, H., and Bandyopadhyay, R. 2008. Rust resistant soybean breeding lines at the International Institute of Tropical Agriculture. Abstract. Paper presented at the Crop Science Society of America Joint Annual Meeting, Houston.

34. Tefera, H., Kamara, A. Y., Asafo-Adjei, B., and Dashiell, K. E. 2009. Improvement in grain and fodder yields of early-maturing promiscuous soybean varieties in the Guinea Savanna of Nigeria. Crop Sci. 49:2037-2042.

35. Tschanz, A. T. 1984. Soybean rust epidemiology. In: Final Report: Asian Vegetable Res. and Development Center. Shanhua, Taiwan.

36. Tschanz, A. T., and Wang, T. C. 1980. Soybean rust development and apparent infection rates at five locations in Taiwan. Prot. Ecol. 2:24-250.

37. Twizeyimana, M., Ojiambo, P. S., Ikotun, T., Ladipo, J. L., Hartman, G. L., and Bandyopadhyay, R. 2008. Evaluation of soybean germplasm for resistance to soybean rust (Phakopsora pachyrhizi) in Nigeria. Plant Dis. 92:947-952.

38. Twizeyimana, M., Ojiambo, P. S., Sonder, K., Ikotun, T., Hartman, G. L., and Bandyopadhyay, R. 2009. Pathogenic variation of Phakopsora pachyrhizi infecting soybean in Nigeria. Phytopathology 99:353-361.

39. Wang, T. C., and Hartman, G. L. 1992. Epidemiology of soybean rust and breeding for host resistance. Plant Prot. Bull. 34:109-124.

40. Yang, X. B., Royer, M. H., Tschanz, A. T., and Tsai, B. Y. 1990. Analysis and quantification of soybean rust epidemics from seventy-three sequential planting experiments. Phytopathology 80:1421-1427. 